\title{
HIGH-RESOLUTION ION-PROBE ANALYSES OF RARE EARTH ELEMENTS IN KIMBERLITIC ZIRCONS.
}

\author{
Kinny, P.D. \\ Research School of Earth Sciences, Australian National University, GPO Box 4, Canberra, 2601, Australia.
}

Certain varieties of kimberlites are known to contain rare accessory zircons which are unusual (although not unique) with respect to typical zircons from upper crustal rocks in that they have large grain-sizes (up to $20 \mathrm{~mm}$ diameter), and they are relatively depleted in the normally abundant trace-elements U, Th, Hf, Y and the REE. They are widely believed to be xenocrysts of deep-seated origin which nevertheless are interpreted (based on documented age relationships) to have a genetic association with kimberlites and related magmas (Kinny et al., 1989). The results of REE abundance measurements of kimberlitic zircons reported here show that they may also possess a unique REE fractionation pattern with respect to zircons from other rock-types and could thus be of increased value as a diamond-indicator mineral in prospecting.

The REE analyses were made on the SHRIMP ion probe at ANU, Canberra, using high mass-resolution in preference to energy-filtering or peak-deconvolution procedures to avoid spectral interferences. By doing so, lower detection limits and higher precision are achieved for the REE than any other microbeam technique. Further, the small inclusions of different minerals which may contaminate bulk chemical analyses are avoided. The REE analyses are performed on the same $25 \mu \mathrm{m}$ scale as U-Pb isotopic analyses, and all fourteen REE are measured.

Figure 1 shows mean chondrite-normalised REE abundances for kimberlitic zircons from the Jwaneng DK2 pipe in Botswana, in comparison with representative crustal zircons (from a zoned plutonic complex in southeastern Australia). Two ages of zircons are present at Jwaneng (as identified with the ion probe, Kinny et al., 1989), an Archaean suite and a Permian suite $(244 \pm 4 \mathrm{Ma})$, the latter corresponding to the pipe age. The Jwaneng kimberlite zircons share certain characteristics of their REE patterns with the crustal zircons : a rise in the light REE abundances from $\mathrm{La}$ to $\mathrm{Gd}$, a positive $\mathrm{Ce}$ anomaly and a negative Eu anomaly. However, the principal differences are best illustrated in Figure 2 in which the REE patterns are normalized to that of the granite zircons. Whereas the other crustal zircons have a similar fractionation of the heavy REE with respect to the granite zircons, the kimberlite zircons show significantly less fractionation. This is particularly the case for the young Jwaneng zircons which have a virtually flat chondrite-normalized heavy REE pattern (Fig.1). Figure 2 also illustrates the smaller magnitude of the $\mathrm{Ce}$ and $\mathrm{Eu}$ anomalies in the kimberlite zircons with respect to the crustal zircons in this instance.

The exact origin of kimberlitic zircons is still unclear, but it appears from the REE data . that they are formed from an extremely fractionated and depleted source with respect to typical crustal melts. This may serve in the future as a useful diagnostic tool for kimberlitic zircons.

Reference : P.D. Kinny, W. Compston, J.W. Bristow and I.S. Williams (1989) Archaean mantle xenocrysts in a Permian kimberlite: Two generations of kimberlitic zircon in Jwaneng DK2, southern Botswana. In: Kimberlites and Related Rocks, Geological Society of Australia Special Publication 14, Volume 2, pp 833-842.

Acknowledgment : The Jwaneng zircons were kindly provided by J.W. Bristow, Anglo American Corp. Ltd Research Laboratory, Johannesburg, South Africa. 


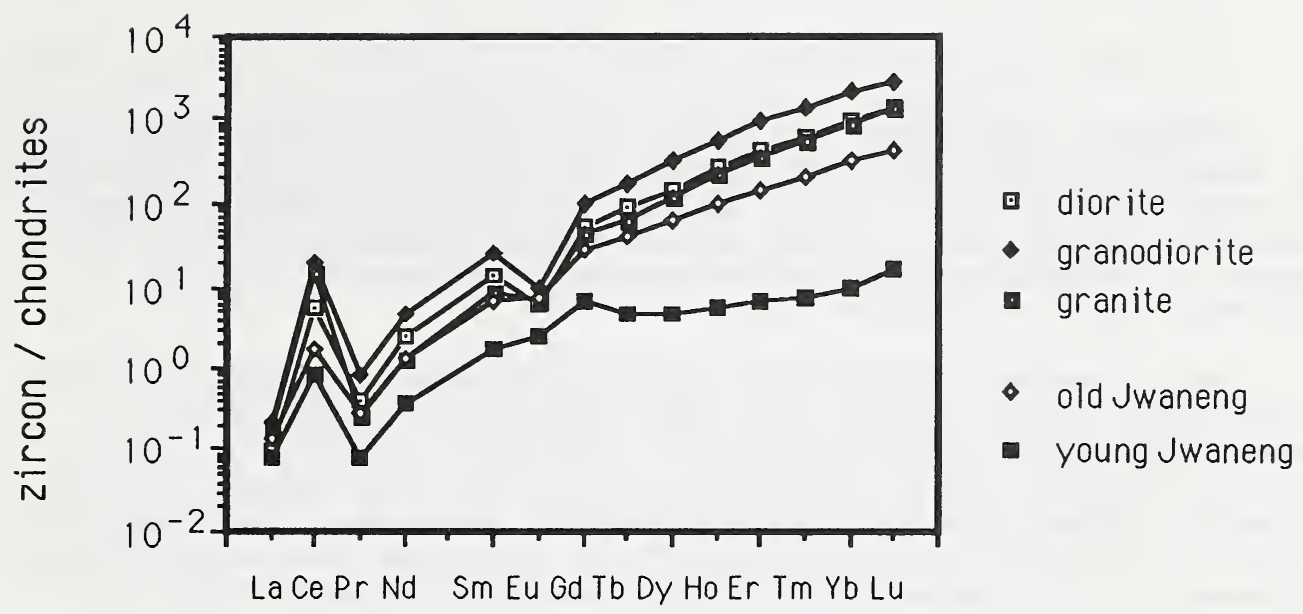

Figure 1

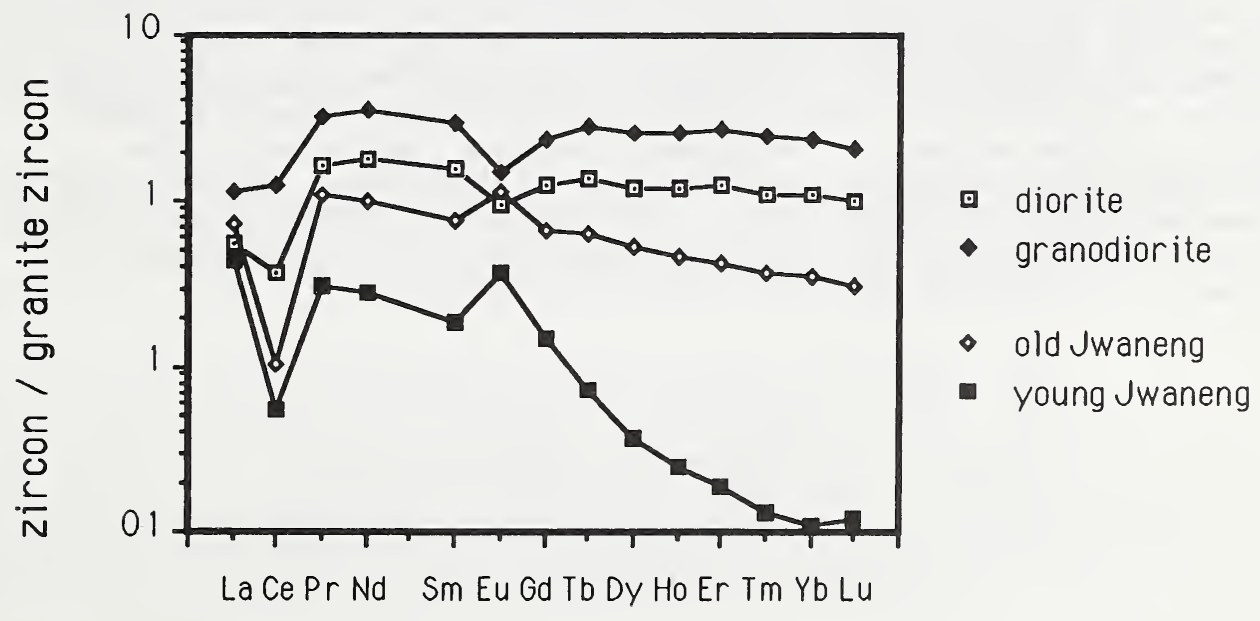

Figure 2 